mendations have been changed to cover situations created by recent technical advances in machine design, and by the development of new radiological techniques. The underlying philosophy, however, remains as it was originally expressed by the Committee thirty years ago, namely, that unnecessary radiation exposure should always be avoided and all exposure kept to the minimum compatible with practical clinical requirements.

\section{Field Studies in Scotland}

Despite the attractiveness of the Study Centre at Garth, the Scottish Field Studies Association may have to discontinue its activities for lack of support. In contrast to the encouraging number of students who are attending Field Study Centres in England, the number of student days spent at Garth fell from 2,972 in 1959 to 2,539 in 1960 . Of the 29 courses offered, 7 had to be cancelled for lack of support. The Association is appealing not only for financial help but also for increased support from Scottish and other local education authorities. In her foreword to the annual report, Dr. Margaret Stewart writes that "there is plenty of lip service to the importance of Field Studies in education curricula, but so long as it is left to the initiative of individual teachers the work of the Association cannot be developed on a firm and lasting basis" (Annual Report, 1960. The Importance of Field Studies in Modern Education. By Paul F. Holmes. Garth House as a Centre for Ecological Botany. By Fred $N$. and Brenda D. Haynes. Pp. $27+4$ plates. (Glasgow: Scottish Field Studies Association, 1961.) 2s. 6d.). Information about the Association can be obtained from 179 West Regent Street, Glasgow 2.

\section{Organization of Sandwich Courses}

THE National Advisory Council on Edueation for Industry and Commerce has started an inquiry on the organization of sandwich courses in technical colleges and other colleges of further education. A sub-committee under the chairmanship of $\mathrm{Mr}$. E. L. Russell, chief education officer for Birmingham, has been set up "to examine the organization of sandwich courses with a view to using college staff, equipment and accommodation and industrial training facilities to the best advantage; and in particular to consider 'end-on' arrangements". The subcommittee is examining the various ways in which practical experience in industry is combined with academic study in technical college courses. These methods include the 'end-on' system by which two quite separate groups of students follow the same course, but use the college alternately, one group being in college while the other is in industry. Any organization or persons wishing to submit evidence to the sub-committee is asked to write to the Secretary, National Advisory Council on Education for Industry and Commerce, Ministry of Education, Curzon Street, London, W.1.

\section{Zoological Society of London}

DURING 1960 the Zoological Society of London was the recipient of three munificent bequests which will enable it to extend considerably its activities. The Trustees of the Nuffield Foundation granted the Society $£ 100,000$ to found an Institute of Comparative Medicine. Mr. Jack Cotton is providing $£ 250,000$ to help the rebuilding programme, and the Ford Founda. tion gave 550,000 dollars (nearly $£ 200,000$ ) to endow research fellowships in animal breeding. A major part of the new research activities will lie in the field of comparative medicine. The Institute of Comparative Medicine is to be associated with the name of Lord Nuffield. The grant is also intended to allow for the creation of two research fellowships in comparative medicine. The Ford grant makes it possible to undertake a systematic study of the reproductive habits and physiology of those animals in the Society's collections which breed readily in captivity. These studies will be supervised by a committee of well-known scientists distinguished for their contributions to knowledge of reproductive physiology. On the basis of the advice of this com. mittee, the Council has already appointed the first three research Fellows. The Society is now planning new laboratories for their accommodation. Mr. Cotton's gift is the key which sets in motion the plan for reconstruction of the Regent's Park Gardens as devised by Sir Hugh Casson and Mr. Peter Shepheard in consultation with the Society's resident architect, Mr. F. A. Stengelhofen. Details of the bequests and other information about the many forward-looking activities of the Society are set out in its annual report for 1960 (Pp. $54+8$ plates. London: Zoological Society of London, 1961). H.R.H. the Duke of Edinburgh has accepted the presidency in succession to Sir Landsborough Thomson.

\section{The Ciba Foundation}

THE report for 1960 of the Ciba Foundation for the Promotion of International Co-operation in Medical and Chemical Research, which includes, as usual, details of symposia and their participants, of the study groups and research meetings, and lists of publications held and issued, records that the Foundation provided accommodation during the year for 825 scientists from 37 countries (Pp. 63. London : Ciba Foundation for the Promotion of International Co-operation in Medical and Chemical Research, 1961). Five three-day international conferences were held and membership of these symposia is now limited to about 30. Besides four one-day study groups, the Foundation arranged five evening discussion meetings, five research meetings, a guest symposium on "Aspects of Ciné-Indoscopy and Ciné-Radiology", seven sessions of scientific films, and a new series of dinner meetings known as the Dunant Coterie. Three such meetings were held in 1960 and the twelfth Ciba Foundation Lecture was delivered by Prof. J. Konorski, the fourth annual lecture on ageing by Dr. $P$. J. Thung, and the Louis Rapkine Lecture by Medicin-Lieutenant M. Flauder. Seven Anglo-French bursaries were awarded by the British selection oommittee for medical graduates to visit France, and two by the French selection committee for visits to London Medical Schools. Three volumes of the proceedings of symposia, one of a colloquium on endocrinology and two of study groups were published during the year.

\section{Photon Rocket}

Optical and mechanical phenomena to be encountered by a space traveller meving with a velocity approaching that of light are discussed by S. M. Rytov (Priroda, 4, 64; 1960). The greatest danger to such a traveller will be encounters with relativistic cosmic dust and wind. A collision of the space ship with a cosmic particle one milligram in weight will spell complete destruction. In spite of such a warning G. G. Zelkin describes the construction of a purely hypothetical photon rocket (Priroda, 11, 